\title{
超音波モータの接触挙動に関する基礎的研究*
}

\author{
中 嶋大智*1, 前田 剛 志*1, 小沢友亨*2 \\ 津久井 道夫*3, 高 塚 公 郎*4, 吉 沢 正 紹*5
}

\section{A Fundamental Study of Contact Behavior of an Ultrasonic Motor}

\author{
Daichi NAKAJIMA, Takeshi MAEDA, Tomoyuki OZAWA, \\ Michio TSUKUI, Kohro TAKATSUKA and Masatsugu YOSHIZAWA*6 \\ ${ }^{* 6}$ Department of Mechanical Engineering, Keio University, \\ 3-14-1 Hiyoshi, Kohoku-ku, Yokohama-shi, Kanagawa, 223-8522 Japan
}

\begin{abstract}
In this paper, we discuss the contact behavior between the stator and the lining material that sticks to the rotor of an ultrasonic motor. The ultrasonic motor is powered by the vibration of the stator and operates with a frictional force between the stator and the lining material. Therefore, it is important to examine the mechanism of the contact behavior to improve the energy efficiency and durability of the ultrasonic motor. We propose a numerical technique using the finite element method to examine the contact behavior between the stator and the lining material. Then, we compare the numerical example with the theoretical solution proposed by L. A. Galin and confirm the validity of our technique. Moreover, on the basis of incremental theory, we use our technique to numerically examine the complex contact behavior of the non-contact zone, slip zone and stick zone in a nonrotating rotor.
\end{abstract}

Key Words : Contact Problem, Frictional Problem, Finite Element Method, Incremental Theory, Ultrasonic Motor

\section{1. 緒 論}

超音波モータは, 駆動力として超音波領域の機械的 振動を利用したアクチュエータである(1). 主に振動子 と移動子から構成され, 振動子に接触させた移動子が, 超音波領域の振動による振動子表面の楕円運動から受 ける摩擦力により駆動力を得る駆動機構をもつ. 超音 波モータは 1982 年に見城, 指田 ${ }^{(2)}$ によって振動片型お よび進行波型タイプが発表され, カメラのオートフォー カス機構やロボットの関節機構等, 先進的分野を中心 に多岐に応用が進んでいる.

これら応用分野に共通しているのは, 精密位置決め 制御が可能で低速高トルクをもつ特性を活かした点で あり, 今後もさらに広範な分野での応用が期待される が, 従来の電磁モータに代わる役割を担うまでには至っ ていない.この主な原因は, 従来の電磁モータやアク チュエータと比較し, 高周波電源や高精度の加工が要

* 原稿受付 2005 年 8 月 23 日.

*1 慶應義塾大学大学院理工学研究科( $\mathbf{M} 223-8522$ 横浜市港北 区日吉 3-14-1)

*2 福井工業大学機械工学科 (画 910-8505 福井市学園 3-6-1).

*3 (株) ミツバ研究部(严376-8555 桐生市広沢町 1-2681)

$* 4$ 正員, 福井工業大学大学院工学研究科.

*5 正員, 慶應義塾大学大学院理工学研究科.

E-mail : dynamics@ mech.keio.ac.jp
求される問題の他，摩擦駆動によるエネルギ変換効率 や移動子接触面の耐久性等の問題が十分に解決されて いない点にある．特に，振動子であるステータと移動 子であるロータの裏面のライニング材との接触は, 局 所的に高い応力が発生する恐れもある.

超音波モータの駆動メカニズムに関しては、ロータ 裏面のライニング材をバネとみなして駆動効率を求め た研究や弾性接触問題としてステータとライニング材 の接触状態を議論したもの等, これまでに数多くの研 究がなされている(3)-(10).これらは，接触領域を全域滑

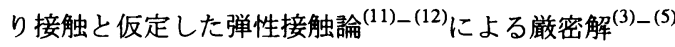
と, 滑り接触および固着接触が混在する実機の接触状 態を有限要素法により解析して求める数值解 ${ }^{(6)}-(10)$ とに 大別される.

前者には, 応力関数を級数展開により近似的に求め ているものや複素数を用いて関数論により求めている もの等があり ${ }^{(3)-(4)}$, ライニング材表面の応力分布の特 性を知る上で有用であるが，半無限弾性体を前提とす る等, 多くの前提が必要であり，厚さ $200 \mu \mathrm{m}$ 程度のラ イニング材に対する解析手法としては適切であるとは いえない.

後者は, 黒沢, 上羽によるライニング材の縦方向変 


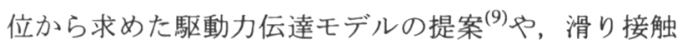
および固着接触が混在する接触領域を仮想線形ばねモ デルを用いて有限要素法により解析する前野の方法 ${ }^{(10)}$ 等がある、現在までに提案されているこれらの解析手 法は, ライニング材の厚さを考虑することができ, 実 用的な方法であるが，ライニング材のせん断変形が考 慮されていない等, より厳密に駆動力を算出する上で は課題の残る手法である.

有限要素法による接触問題の解析手法としては, 変 分原理に摩擦の項を考慮した解法 ${ }^{(13)}$-(15)や, 解析時間 を著しく短縮する乾燥接触モデル $(\mathrm{DCM})^{(16)}$ 等があるが, 本研究では単純な三角形平面ひずみ一次要素のみを用 い, 滑り接触領域に対してクーロン摩擦を前提とし, ライニング材のせん断変形を考慮したステータとライ ニング材の接触メカニズムを解明する解析手法を提案 した.さらに，固着接触領域を含まない接触問題に対 するこの手法による数值解を L. A. Galin の弾性接触論 (11)に基づく峳密解と比較することによって, その妥当 性を検証した。

次に, 固着接触領域を含む接触問題を本手法により 解析したが, ライニング材の変形および応力状態は, そ の接触過程に依存する. すなわち最終的なステータの 位置が同じでも変形過程が異なればライニング材の変 形および応力の状態は異なる.したがって, 本研究で は増分理論 ${ }^{(17)}$ に基づいて非接触, 滑り接触および固着 接触の混在する一般の接触問題の解析を行なった。 た だし, 本研究で行った解析は, 超音波モータの駆動メ カニズム解析の前段階としてのロータが回転しない静 的な場合である。

\section{2. 解析手法の検証と铰密解の適用範囲}

滑り領域に対してクーロン摩擦を前提とし, ライニ ング材のせん断変形を考虑したステータとライニング 材の非接触, 滑り接触および固着接触の接触メカニズ 厶を三角形平面ひずみ一次要素を用いた有限要素法に より解明する解析手法を提案する。 また, 本手法によ り得られた解と半無限大厚さに対する L. A. Galin の厳 密解との比較により本解析手法の妥当性を検証すると ともに厳密解が適用できる弾性体の大きさを明らかに する.

\section{$2 \cdot 1$ 本研究の解析手法}

2.1.1 接触領域の決定法と解析手順 図 1 に示寸 ライニング材表面の各節点 $\mathrm{A}, \mathrm{B}, \cdots, \mathrm{I}$ が，ステータに押 されて $\mathrm{a}, \mathrm{b}, \cdots, \mathrm{i}$ に変位する場合について考える.はじ めに, 接触領域を適当に, 例えば節点 $\mathrm{C}, \mathrm{D}, \cdots, \mathrm{G}$ と仮定 し, これらの節点の垂直方向変位を強制変位として解
析する. 接触領域の垂直方向の節点力は圧縮力となる べきであるから，解析結果において，節点 C,D, , G の うち引張力となっている節点があればその節点を非接 触領域として再度解析する。 また, 非接触領域内の節 点 A,B,H,I の垂直方向変位は, 常にステータの上にあ るべきであるから，下になっている節点があれば接触 領域として再度解析する. 本手順により, 接触領域お よび非接触領域に矛盾がなくなるまで修正を繰り返し， 接触領域を決定する.

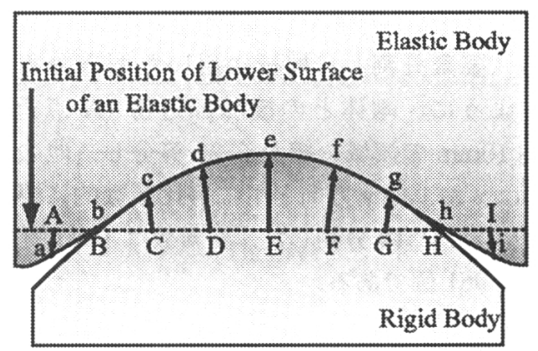

Fig. 1 Method of determinating the contact zone

2.1 .2 解析モデル 前述の解析手法により, 剛体 (ステータ)の平均半径 $r=30 \mathrm{~mm}$, 振動波次数 $n=9$ の 場合の解析を行い, 次節の厳密解と比較した。対称性 および周期性を利用して, 解析対象領域は振動波形の $1 / 2$ の領域とし, 剛体との接触領域の弾性体 (ライニン グ材) の $y$ 方向強制変位 $v$ は, 次式で表されるものと した.

$$
\begin{aligned}
v & =h(x)+y_{0}=a_{0} \cos \left(\frac{n x}{r}\right)+y_{0} \\
& =a_{0} \cos (0.3 x)+y_{0}
\end{aligned}
$$

ここで, $y_{0}$ および $a_{0}$ は図 2 に示すように弾性体下 面から剛体表面の中心までの距離および剛体の振幅で ある. 解析は, 振幅 $a_{0}=2 \mu \mathrm{m}$, ヤング率 $E=900 \mathrm{MPa}$, ポアソン比 $v=0.45$, 摩擦係数 $\mu=0$ および 0.2 とし, 相対位置 $y_{0}=-1 \sim 7 \mu \mathrm{m}$ の範囲で行った. 弾性体上面 はロータに固着されているため, $x$ および $y$ 方向変位を 0 とし, また, 左面および右面の $x$ 方向変位も対称性お よび周期性より 0 とした. なお, 剛体上面は式 (1) で示 される曲線であるため, 接触面の変位の境界条件には 傾斜面に接触する条件を用いるべきであるが, その最 大傾斜角 $\tan \theta_{\max }$ は

$$
\begin{aligned}
\tan \theta_{\max } & =\left|\frac{d v}{d x}\right|_{\max }=\left|-\frac{a_{0} n}{r} \sin \left(\frac{n x}{r}\right)\right|_{\max } \\
& =\frac{a_{0} n}{r}=6 \times 10^{-4}
\end{aligned}
$$

となり非常に小さいので, 傾斜角を無視して水平面に 接触する条件を用いた. 


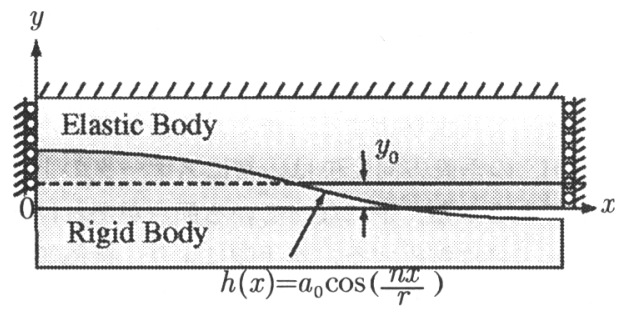

Fig. 2 Position of an elastic body and a rigid body

2.1.3 要素分割解析に用いた要素分割は図 3 に示すように，剛体との接触部近傍 (A 点近傍) の $10 \mathrm{~mm} \times 10 \mathrm{~mm}$ の領域を細かく20 等分し，他の領域に 対しては $x$ および $y$ 方向ともに等比級数的に要素が大 きくなるように 10 分割した. 要素数は 1800 個であり, 節点数は 961 個である.

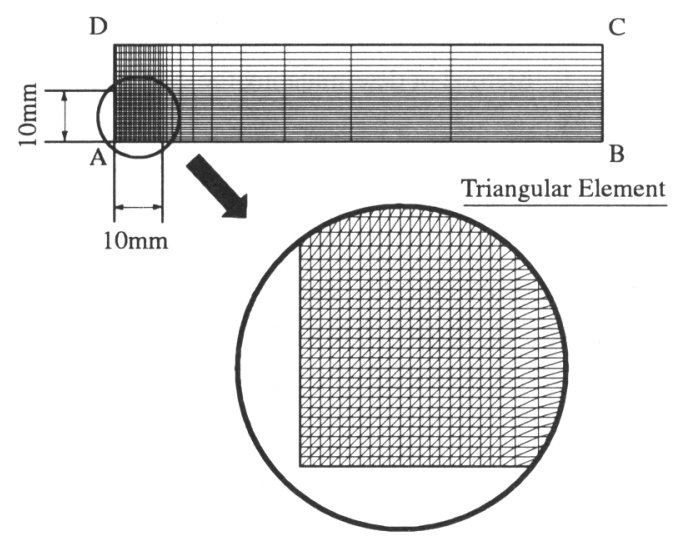

Fig. 3 Element division of an elastic body

\section{2 半無限弾性体の厳密解}

2.2.1 L. A. Galin の弾性接触理論 図 4 に示す剛 体と半無限弾性体の接触問題について考える.

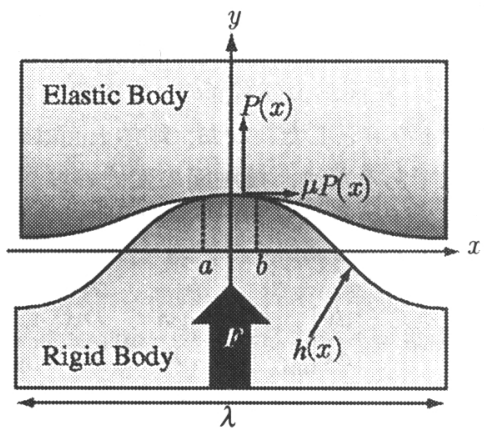

Fig. 4 Analytical model of elastic contact problem
弾性体は一定の押付荷重 $F$ で剛体に押付けられ，接 線方向に摩擦力 $\mu F$ を受けて釣合状態にあるとすると, 弾性体表面の境界条件は以下のようになる。

$$
\begin{array}{lr}
\tau_{x y}=\mu \sigma_{y} & a<x<b \\
v=h(x)+\mathrm{const} & a<x<b \\
\sigma_{y}=\tau_{x y}=0 & x<a, b<x
\end{array}
$$

ここで， $\sigma_{y}$ および $\tau_{x y}$ は弾性体に働く垂直および接線 応力であり, $v$ および $h(x)$ は弾性体の $y$ 方向変位およ び接触界面における剛体の形状を表す関数である. L. A. Galin の弾性接触論 ${ }^{(11)}$ 上り接触領域 $a<x<b$ におけ る $\sigma_{y}, \tau_{x y}$ および $v$ の関係は接線方向変位 $u$ を用いて次 のように表すことができる.

$$
\begin{aligned}
& \frac{\pi E}{2\left(1-v^{2}\right)}\left(\frac{\partial u}{\partial x}\right)_{y=0} \\
& =-\int_{a}^{b}\left(\tau_{x y}\right)_{y=0} \frac{d t}{t-x}+\frac{1-2 v}{2-2 v} \pi\left(\sigma_{y}\right)_{y=0} \\
& \frac{\pi E}{2\left(1-v^{2}\right)}\left(\frac{\partial v}{\partial x}\right)_{y=0} \\
& =-\int_{a}^{b}\left(\sigma_{y}\right)_{y=0} \frac{d t}{t-x}-\frac{1-2 v}{2-2 v} \pi\left(\tau_{x y}\right)_{y=0}
\end{aligned}
$$

これらの応力と変位の関係式を Riemann-Hilbert 問題に 帰着して解くと, 弾性体表面の垂直方向応力 $\left(\sigma_{y}\right)_{y=0}$ は 次のようになる.

$$
\begin{aligned}
\left(\sigma_{y}\right)_{y=0}= & \frac{E}{2\left(1-v^{2}\right)\left(1+\gamma^{2}\right)(x-a)^{\theta}(b-x)^{1-\theta}} \\
& \times \int_{a}^{b} \frac{h^{\prime}(t)(t-a)^{\theta}(b-t)^{1-\theta}}{t-x} d t \\
& -\frac{E \gamma}{2\left(1-v^{2}\right)\left(1+\gamma^{2}\right)} h^{\prime}(x) \\
& -\frac{c \sin \pi \theta}{(x-a)^{\theta}(b-x)^{1-\theta}}
\end{aligned}
$$

ここで, $\gamma$ および $\theta$ は

$$
\left\{\begin{array}{l}
\gamma=\mu \frac{1-2 v}{2-2 v} \\
\theta=\frac{1}{\pi} \tan ^{-1}\left(-\frac{1}{\gamma}\right) \quad(0<\theta<1)
\end{array}\right.
$$

である. 接触領域の両端 $(x=a, x=b)$ における境界条 件 $\left(\sigma_{y}\right)_{y=0}=0$ を式 (6) に適用すると

$$
\begin{gathered}
\int_{a}^{b} \frac{h^{\prime}(t)}{(t-a)^{1-\theta}(b-t)^{\theta}} d t=0 \\
\frac{1}{\left(1-v^{2}\right)\left(1-\gamma^{2}\right)} \int_{a}^{b} \frac{(a+b-t) h^{\prime}(t)}{(t-a)^{1-\theta}(b-t)^{\theta}} d t \\
-c \sin \pi \theta=0
\end{gathered}
$$

が得られる。種々の $a$ に対して上式より $b$ および $c$ を 求めれば, 式 (6) より接触領域の接触面圧および押付荷 重を求めることができる. 
2.2.2 解析モデル 前節と同じ条件を想定して， $-6 \mathrm{~mm}<a<-1.5 \mathrm{~mm}$ の範囲の面圧分布および押付荷重の 厳密解を求め, 本研究の解析手法による解と比較した. なお，これらの演算に必要な積分区間端点での特異積 分の解析には, 二重指数関数型数值積分公式 (DE 公式) を用いた。

$\mathrm{DE}$ 公式では，積分区間内に不連続点や特異点がある 場合には精度が著しく低下する. しかしながら本例の ように特異性が積分区間の端点に限られる場合には精 度の高い結果を得ることができる．したがって本研究 においては被積分関数を収束性の極めて強い関数に置 換し，解析を行った.

2.3 解析手法の検証と敩密解の適用簿囲 図 3 に 示す要素分割を用い，弾性体の厚さ $\mathrm{AD}$ を 10,50 およ び $200 \mathrm{~mm}$ として，解析を行った．ただし，各解析にお ける長さ $\mathrm{AB}$ はそれぞれ 50,250 および $1000 \mathrm{~mm}$ と十 分大きくした．摩擦がない場合の接触幅と押付荷重の 関係を図 5 に示す，同図には，弾性体の厚さが無限大 である厳密解も併記したが，弾性体が厚くなるほど押 付荷重は减少し，厳密解に漸近している.

摩擦が存在する場合には，一般に接触領域に固着領 域が存在するが，この場合の厳密解を得ることは困難 である.したがって厳密解との比較を容易にするため, 接触領域全域が滑り領域である厳密解と同じ条件で解 析した. 図 6 に摩擦係数 $\mu=0.2, \mathrm{AD}=10 \mathrm{~mm}$ および $200 \mathrm{~mm}$ の場合の結果を厳密解とともに示寸. $\mu=0$ の 場合の図 5 と同様, 十分な厚さの弾性体の解は, 無限 大厚さの厳密解と一致している.

接触幅 $w=4 \mathrm{~mm}$ および $12 \mathrm{~mm}$ の場合の接触面圧を 図 7 および図 8 に示す。これらの図も，図 5 および図 6 と同様に十分な厚さの弾性体の解は, 無限大厚さの厳 密解と一致している．以上述べた図 5〜図 8 の結果は, 十分な厚さの弾性体の数值解は無限大厚さの厳密解と 一致することを意味し，本研究で提案した解析手法の 妥当性を示している。

解析手法の妥当性の検証は, 実験的に行うのが一般 的である. しかし, 本研究の超音波モー夕の接触問題 では，ステータの形状を表す式(1)の振幅 $a_{0} か ゙ ~ 2 \mu \mathrm{m}$ 程 度と非常に小さいため, 図 3 の辺 $\mathrm{AB}$ 上の連続する 20 の節点間の $\mathrm{y}$ 方向変位差は，小さいところでは $25 \mathrm{~nm}$ 程 度である.このような形状の接触状態の実験を行うこ とは機械加工面からも非常に困難である. したがって, 本研究では解析手法の妥当性の検証方法として, 上述 のように厳密解の得られている無限大厚さの解との比 較による手法を用いた。

また，図5〜図 8において弾性体の厚さが 10mm から

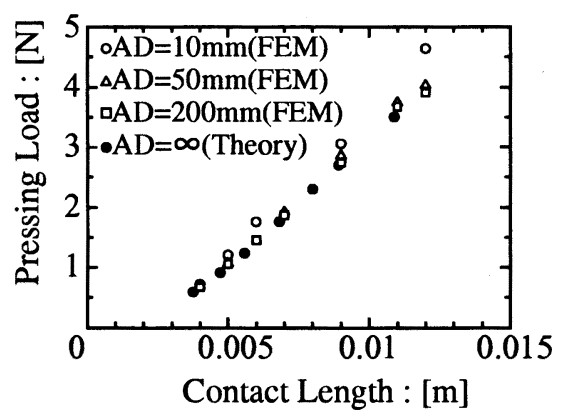

Fig. 5 Contact length and pressing $\operatorname{load}(\mu=0)$

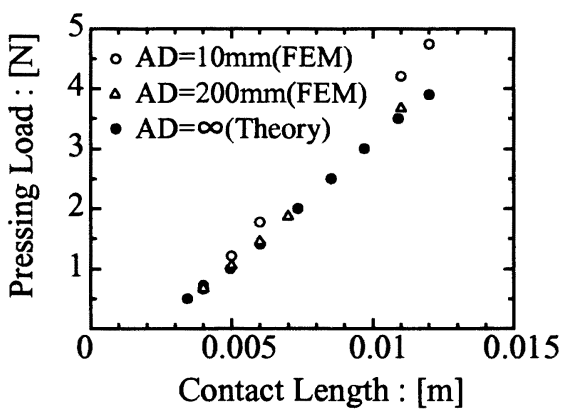

Fig. 6 Contact length and pressing $\operatorname{load}(\mu=0.2)$

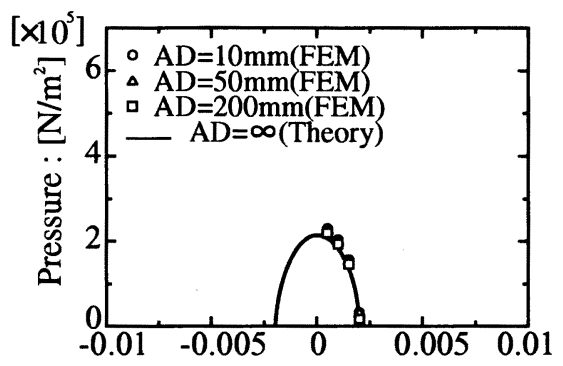

Position of an Elastic Body : [m]

Fig. 7 Pressure distribution $(w=4 \mathrm{~mm}, \mu=0.2)$

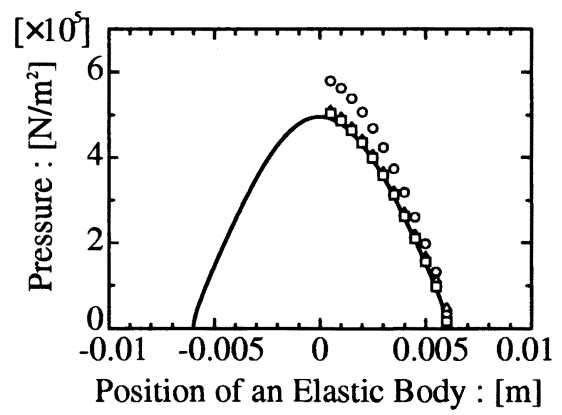

Fig. 8 Pressure distribution $(w=12 \mathrm{~mm}, \mu=0.2)$ 
$50 \mathrm{~mm}$ に増大すると, 押付荷重および接触面圧は急激 に厳密解に近づき,さらに，200mmに増大しても，あ まり変化しない.これは, 厚さ $200 \mathrm{~mm}$ の弾性体は半無 限弾性体とみなすことができ，このような条件での弾 性接触問題の場合, 半無限大厚さの厳密解が適用でき る弾性体厚さは $200 \mathrm{~mm}$ 以上であることを示している.

一般に曲率をもった接触面に生じる局所的な応力に 関しては弾性論による半無限弾性体の解が広く恋知さ れており、これらの解がどのような場合に適用できる かを知ることは，非常に重要な課題である.

本章の結果は弾性接触問題において半無限弾性体の 厳密解が適用できる弾性体厚さの下限を定量的に明らか にしており，上記の観点においても重要な意義をもつ.

\section{3. ステータとライニング材の接触メカニズム}

峳密解との比較により妥当性が検証できた本研究の 解析手法を適用して, 有限要素法による弾塑性変形解 析の一般的な解析手法である増分理論 ${ }^{(17)} に よ り$, 非接 触, 滑り接触および固着接触の混在する接触問題の解 析を行なった.

ただし, 本研究で行った解析は, 超音波モータの駆 動メカニズム解析の前段階としてのロータが回転しな い静的な場合である.

3.1 接触メカニズムの解析手法 ライニング材に ステータが接触する問題では, 摩擦係数が 0 でない場 合, 接触領域に滑り接触領域と固着接触領域が混在す るため, 接触挙動は非線形となる. したがって, 本研究 では増分理論により解析を行ない, 各解析段階でのス テータの相対位置 $y_{0}$ の増加量 $\Delta y_{0}$ は, 接触節点数が一 つ増加する量とした．具体的な解析手順は図 9 に示す ように, はじめに一節点のみ固着接触している条件で, 相対位置 $y_{0}$ に対する任意の増分 $\Delta h$ を仮定して解析す る. その結果より非接触側の隣の節点が接触するとき の増分 $\Delta y_{0}$ を求める. この第一段階では, 唯一の実質 的に接触している節点 (外力が押付力となっている節 点）は滑りが生じないため, 固着条件として解析した ことに矛盾は生じない. 次に接触節点をさらに一つ増 加させ, 同様の手順により非接触側の隣の節点が接触 するときの增分 $\Delta y_{0}$ を求めて解析する. この第二段階 では，実質的に接触している飾点が二つあるが，これ らの点に対し接触条件に矛盾がないことを確認し，矛 盾があれば次のように修正して再度解析を行う。

固着領域では, 水平方向の節点外力すなわち摩擦力 は, 摩擦係数から求められる静止摩擦力以下でなけれ ばならない $(|X / Y|<\mu)$ から, 静止摩擦力以上になっ ていれば，その節点を滑り領域として再度解析する.
また，滑り領域では，摩擦力すなわち節点の水平方向 外力は節点変位と反対方向に做かなければならない $(u \cdot X<0)$ から，これらが同方向であればその節点を固 着領域として再度解析する. 以上の手順を綵返し, 矛 盾がない解析結果が得られれば，次に接触䈨点をさら に一つ増加させて同様の手順を練返し，解析を進める.

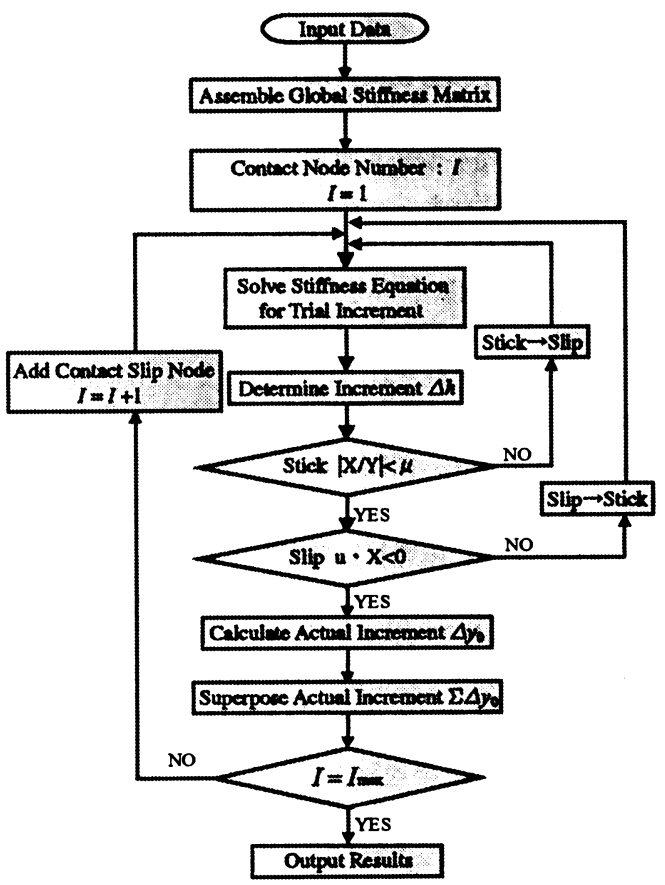

Fig. 9 Flow chart of numerical analysis

3.2 解析モテルおよひ高基分揢 ステータとライ ニング材の接触問題を 2.3 節と同じ条件により解析し た. ただし、ライニング材の厚さ $t$ は実際の超音波モー 夕を想定して $t=\mathrm{AD}=0.2 \mathrm{~mm}$ とし, 水平方向の解析対 象長さ $\mathrm{AB}$ はステータの変形の半波長分

$$
\frac{1}{2} \times \frac{2 \pi r}{n}=10.47 \mathrm{~mm}
$$

とした.

ライニング材の水平方向の分割数は接触領域が $\pm 0.1 \mathrm{~mm}$ の精度で得られるように 105 分割した。 また, ライニング材厚さは接触幅に比べて非常に薄く、ライ ニング材の厚さ方向の応力変化は小さいと推定される ため, 厚さ方向分割数は少なくても高精度の解が得ら れることが予想される. はじめにライニング材の厚さ 方向分割粗さの解析精度に及ほす影都を調べるため, 4 等分と 8 等分の両方の解析を行った. 厚さ方向分割が 4 等分の場合の分割を図 10 に示す. 
表 1 に摩擦俰数 $\mu=0$, ポアソン比 $v=0.45$, ステー 夕の相対位置 $y_{0}=0 \mu \mathrm{m}$ の場合の解析結果を示す. 接 触幅 $w$ は, 目標精度の $\pm 0.1 \mathrm{~mm}$ の範囲内で一致してお り, また各位置の接触面圧 $\sigma_{y}$ も $\pm 0.01 \mathrm{MPa}$ の範囲内で 一致している. 以上の結果より, 厚さ方向の分割は 4 等分で十分な精度が得られることが明らかとなったの で, 以後の解析は全て図 10 に示寸 4 等分の要素分割で 行った。

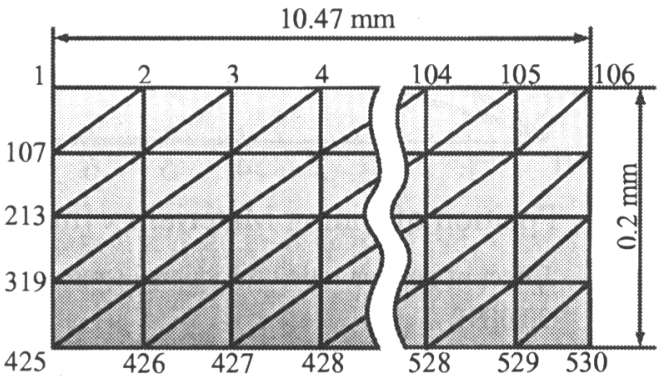

Fig. 10 Dimension and element division of a lining material (4 divisions in thickness direction)

Table. 1 Contact Width $w$ and Pressure $\sigma_{y}$

\begin{tabular}{|c|c|c|}
\hline & \multicolumn{2}{|c|}{ Divisions } \\
\cline { 2 - 3 } & 4 & 8 \\
\hline Contact Width $: w[\mathrm{~mm}]$ & 5.5 & 5.5 \\
\hline Pressure $: \sigma_{y}[\mathrm{MPa}]$ & & \\
$x=1 \mathrm{~mm}$ & 15.66 & 15.66 \\
$x=2 \mathrm{~mm}$ & 13.69 & 13.68 \\
$x=3 \mathrm{~mm}$ & 10.52 & 10.51 \\
$x=4 \mathrm{~mm}$ & 6.50 & 6.50 \\
$x=5 \mathrm{~mm}$ & 2.22 & 2.22 \\
\hline
\end{tabular}

$3 \cdot 3$ 接触メカニズム

3.3.1 接触メカニズムの一般的な特徴 ステータ の位置 $y_{0}=0 \mu \mathrm{m}$, 摩擦倸数 $\mu=0.2$ およよ゙ポアソン比 $\boldsymbol{v}=0.45$ の場合の解析結果を図 11〜図 13 に示寸. 図 11 より明らかなように, 接触領域は $5.2 \mathrm{~mm}$ であるが, 大部分の $5.0 \mathrm{~mm}$ が固着接触であり，滑り接触は残りの 僅か $0.2 \mathrm{~mm}$ である．なお，参考のため，同図の右上に 非接触領域と接触領域の境界近傍のライニング材の変 形状態を搪大して示した。

摩擦応力は図 12 に示すように, 固着領域では滑り領 域に近づくにつれて大きくなるが，ある程度近づくと 減少し始め, 滑り領域では非接触領域に至るまで単調 に減少している，接触領域の摩擦係数は図 13 に示すよ うに, 固着領域では最大静止摩擦係数以下であり，滑 り領域では一定の摩擦係数の值となっており, 前提と した摩擦条件を満たしている。

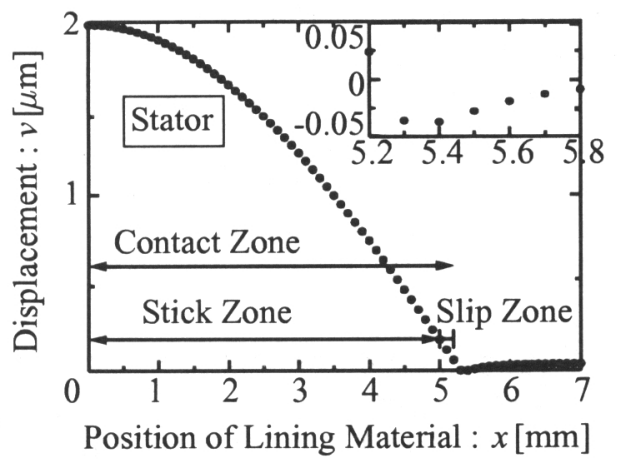

Fig. 11 Displacement of lining material

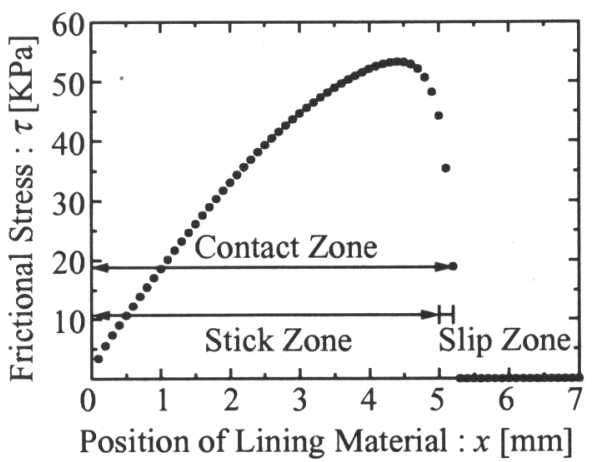

Fig. 12 Frictional shear stress of contact zone

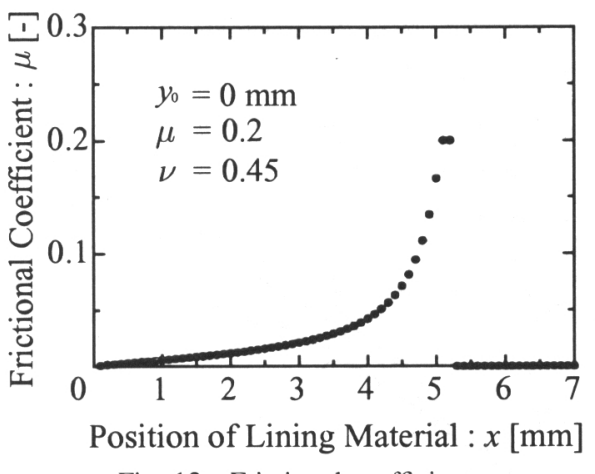

Fig. 13 Frictional coefficient

以上の結果より, ステータとライニング材の接触メ カニズムは, 従来の接触領域全域を滑り領域と仮定し て導かれたものとは全く異なることが明らかとなった。 超音波モー夕の最も重要な因子の一つである駆動力 は, 摩摖応力を積分して求められる。そこで, 摩擦応 力に及ぼす各パラメータ，すなわちステータの相対位 置 $y_{0}$, 摩擦係数 $\mu$ およびポアソン比 $v$ の影響について, 次に述べる。 
3.3.2 ステータの相対位置 $y_{0}$ の影暃 ステータの 位置 $y_{0}=-1,0$ および $1 \mu \mathrm{m}$ の場合の摩擦応力を図 14 に示す. ステータがライニング材に接近する $y_{0}$ が大き くなる)につれ接触領域は増大し, 摩擦応力から求めら れる摩擦力は増大寸るが, 摩擦応力の分布パターンは あまり変化せず，ステータの相対位置 $y_{0}$ の影響を殆ど 受けない.

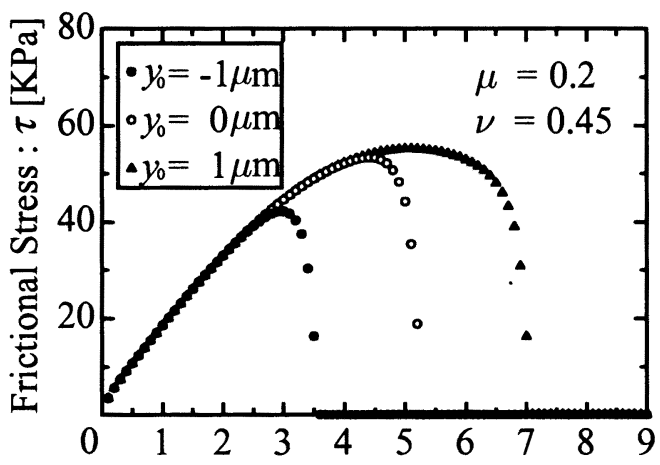

Position of Lining Material : $x[\mathrm{~mm}]$

Fig. 14 Effect of stator position on frictional stress

3.3.3 摩撩係数 $\mu$ の影響 摩擦係数 $\mu=0.1,0.2$ および 0.3 の場合の摩擦応力を図 15 に示す. 接触領域 は固着領域が支配的で滑り領域は少なく，また接触面 積もあまり変化しないため, 摩擦応力したがって, 駆 動力は摩擦係数の影響をあまり受けない。

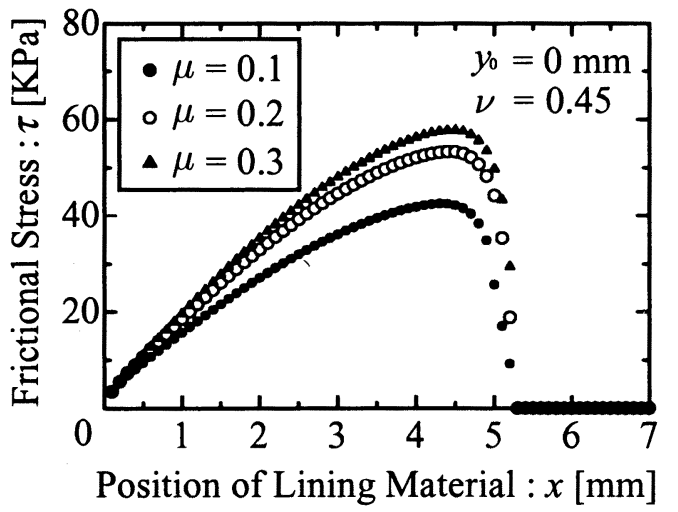

Fig. 15 Effect of frictional coefficient on frictional stress

3.3.4 ポアソン比 $v$ の影響 押付力 $F_{y}=90.0[\mathrm{~N}]$ に対して, ポアソン比 $v=0.42,0.45$ および 0.48 の場 合の摩擦応力分布を図 16 に示す. 押付力 $F_{y}$ が一定の 場合, ポアソン比 $v$ が 0.5 に近づくとライニング材の 非圧縮性の影響が強く現れて接触面圧が急激に増大寸
るため, 接触面積は减少し，摩擦応力および駆動力は 急激に增大する.

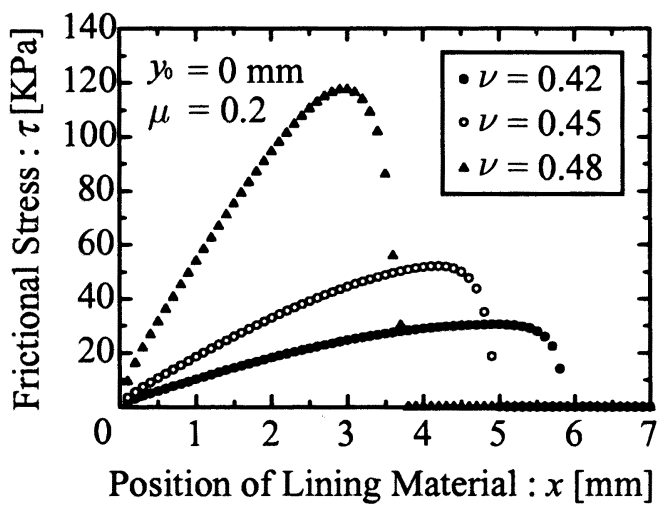

Fig. 16 Effect of poisson ratio on frictional stress $\left(F_{y}=\right.$ $90.0[\mathrm{~N}])$

3.4 接触領域一定の接触メカニスム 以上の解析 は, 形状が一定のステータが下から上昇してライニン グ材の接触領域が少しずつ増加していく変形過程を想 定した場合であり，この変形過程は非線形であったが， 参考として、ステータとの接触領域が変化せず，ステー 夕の形状が直線から振幅のみ大きくなる変形過程に対 する解析を行なった. 図 17 に摩擦応力の解析結果を示 すが, 同図より明らかなように,この変形過程では固 着一滑り接触境界付近に摩擦応力の急峻なピークが発 生しており，この傾向は L. T. Campos の結果 ${ }^{(13)}$ とよく 一致している.

また, 図 16 と図 17 の比較により, ライニング材に 発生する応力状態は, その接触過程に大きく依存する ことがわかる。

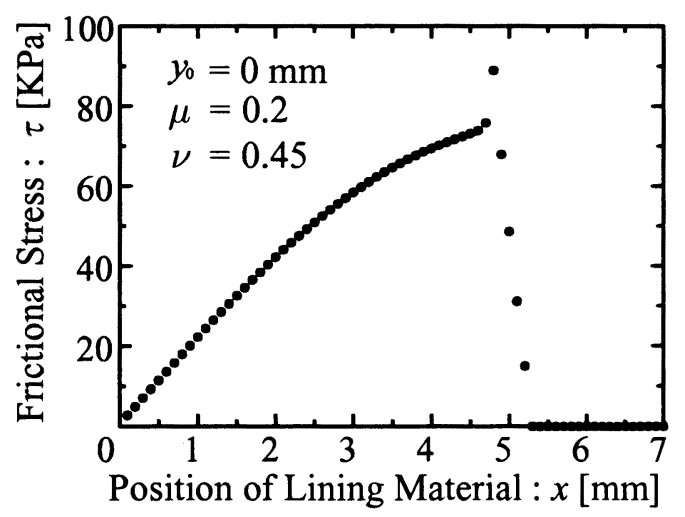

Fig. 17 Frictional shear stress of contact zone 


\section{4. 結論}

本研究では，クーロン摩擦を前提とし，せん断変形 を考虑して非接触, 滑り接触および固着接触の三領域 が共存するステータとライニング材の接触メカニズム を有限要素法により数值的に解明した. またこれに 先立って, L. A. Galin の弾性接触論に基づく厳密解と の比較により，ここで用いた数值解析手法の妥当性を 検証した。

さらに，本手法に増分理論を適用し，超音波モータの 動的な駆動解析の前段階として, ステータとライニン グ材の静的な非線形接触メカニズムを明らかにし, 従 来知られていなかった以下の知見を得た。

1) 摩擦係数 $\mu=0.1 \sim 0.3$ の範囲では, 接触領域は固 着領域が支配的であり，接触面積，接触面圧およ び摩擦応力はあまり変化しない.

2) 押付力が一定の場合, ライニング材のポアソン比 $v$ が 0.5 に近づくと，すなわち非圧縮性材料に近づ くと, 接触面積は減少し, 接触面圧および摩擦応 力は急激に増大する.

3) ライニング材に発生する摩擦応力はステータとの 接触過程に大きく依存し, 接触領域が徐々に増加 する接触過程では摩擦応力の急峻なピークは発生 しない.

本研究で確立した手法を用いて、ロータが回転中の 動的な接触メカニズムの解析を行い, 超音波モータの 課題であるエネルギ変換効率やライニング材の耐久性 の向上を図ることが今後の課題である.

\section{謝辞}

本研究を進めるにあたり, 合同報告会および各種勉 強会において御尽力を賜り，有益なディスカッション をさせて頂いた株式会社ミツバ 阿久戸庸夫氏, 関口武 氏，並びに，慶應義熟大学大学院海老原義彦氏，田島 克彦氏，㺵野仁志氏，中島健氏に謝意を表します。

\section{文献}

(1) Hagedorn, P. and Wallaschek, J., Traveling Wave Ultrasonic Motors, Partl: Working Principle and Mathematical Modeling of the Stator, Jouurnal of Sound and Vibratgion, Vol.155, No.1(1992), pp.31-46.

(2) Kenjo, T. and Sashida, T., Introduction to the Ultrasonic Motor (in Japanese), (1991), pp.7-15,Sougou Denshi Shuppan.
(3) Zharii, O. Y. and Ulitko, A. F., Smooth Contact between the Running Rayleith Wave and a Rigid Strip, Journal of Applied Mechanics, Vol.62, No.2(1995), pp.362-367.

(4) Zharii, O. Y., Adhesive Contact between the Surface Wave and a Rigid Strip, Journal of Applied Mechanics, Vol.62, No.2(1995), pp.368-372.

(5) Tsukui, M. et al., Analysis of Stresses in the Elastic Material near the Contact Face of a Ultrasonic Motor Using the Theory of Elastic Contacts, Proceedings of Dynamics and Design Conference 1998, Japan Society of Mechanical Engineers, No.98-8(I)(1998-8), pp.347-350.

(6) Maeno, T. and Bogy, D. B., Effect of the Rotor/Stator Interface Condition including Contact Type, Geometry, Material on the Performance of Ultrasonic Motors, Transactions of the ASME, Vol.116, No.4(1994), pp.726732.

(7) Takatsuka, K. et al., Analysis of the Driving Mechanism for an Ultrasonic Motor. Part 1: A Study on a Numerical Analysis of the Contact Behavior between a Rotor and a Stator, Proceedings of Dynamics and Design Conference 2000, Japan Society of Mechanical Engineers, No.006(2000-9), pp.327-331.

(8) Takatsuka, K. et al., Driving Mechanism of an Ultrasonic Motor. Part 2. Contact Behavior between a Rotor and a Stator, Proceedings of JSME Millennium 2001, No.014(2001-8), 157-158.

(9) Kurosawa, M. and Ueha S., Efficiency of ultrasonic motor using traveling wave, Journal of the Acoustical Society of Japan, Japanese Edition, Vol.44, No.1(1988), pp.40-46.

(10) Maeno, T., Contact analysis of traveling wave type ultrasonic motor considering stick/slip condition, Journal of the Acoustical Society of Japan, Japanese Edition, Vol.54, No.4(1998), pp.305-311.

(11) Galin, L. A., Contact Problems in the Theory of Elasticity (in Japanese), (1958), pp.14-68, Gendai Kogaku-sha.

(12) Johnson, K. L., Contact Mechanics, (1985), pp.11-35, CAMBRIDGE UNIVERSITY PRESS

(13) Campos, L. T. et al., A numerical analysis of a class of contact probrem with friction in elastostatics, Computer Method in Applied Mechanics and Engineering, Vol.34, No.1(1982), pp.821-845.

(14) Chandrasekaran, N. et al., A finite element method for contact probrems with friction, International Journal for Numerical Method in Engineering, Vol.24, No.3(1987), pp.477-495.

(15) Barber, J. R. and Ciavarella, M., Contact mechanics, International Journal of Solid and Structures, Vol.37, No.12(2000), pp.29-43.

(16) Kang, Y. S. et al., A finite element model for spherical debris denting in heavily loaded contacts, Journal of Tribology, Vol.126, No.1(2004), pp.71-80.

(17) For example, Takatsuka, K., A study of elastic-plastic deformation of a bar and a column, PhD Thesis, University of Tokyo, (1973), pp.37-45. 